\title{
GEICAM, a Spanish Cooperative Research Group in Breast Cancer
}

GEICAM (Spanish Breast Cancer Research Group) was set up in 1995 with an ambitious and innovative objective that has held firm ever since: for Spanish researchers to be able to carry out their own clinical research projects in breast cancer, as well as to provide information to patients about their treatment options and to promote their participation in clinical trials.

Currently, around 660 multidisciplinary professionals working in 176 hospitals throughout Spain belong to this group. A highly professional team specialised in developing clinical trials related with this disease with two identifying aspects: multidisciplinarity and cooperation.

For GEICAM, the future for the treatment of breast cancer implies a multidisciplinary approach, i.e., with teams of professionals in hospitals comprising the different specialists involved in prevention, diagnosis, research and treatment: radiologists, pathologists, biologists, surgeons or gynaecologists, radiation oncologists and medical oncologists, among others. One of the basic principles of our work philosophy is the promotion of collaboration between the experts involved in the prevention and treatment of this tumour and that of specialists in molecular biology and genetics. On this point we have established collaboration agreements with Spanish centres of excellence in the field of basic research so as to relate biological findings with patients' clinical evolution. Our aim is to offer a global, and not merely a local vision of breast cancer. In this context and as a cooperative group we collaborate actively with other international institutions such as the Cancer International Research Group (CIRG), the Breast International Group (BIG), the German Breast Group (GBG), the National Cancer Institute of Canada, the MD Anderson Cancer Center (University of Texas) and the National Surgical Adjuvant Breast and Bowel Project (NSABP).
In 2005 we contributed to the creation of CIBOMA (Coalición Iberoamericana de Oncología Mamaria), an international non-profit cooperative group, dedicated to promote research in the field of breast cancer through an international network of groups established in Spain, Latin America and Portugal, countries that share a common culture. The beginnings were not easy, as some research groups were not used to conduct clinical trials in an international context. This has been one of the goals that were hardest to achieve for CIBOMA. Nowadays we are conducting the CIBOMA/200401-GEICAM/2003-11 study [1-3], one of the first clinical trials conducted in the adjuvant treatment of triple negative breast cancer patients; results will be available in about one and a half years from now.

Finally, our group considers it a priority to establish a relationship with the patients. Patient advocacy groups, particularly FECMA, the Spanish Federation of Breast Cancer Patients, are invited to actively participate in GEICAM meetings; a 6-h special meeting is held for them in parallel with the International GEICAM symposium. In the end, breast cancer patients and survivors constitute the collective for whom we work; they and all the women who may suffer from the disease in the course of their lives. We pay particular attention, then, to disseminate clear information about breast cancer not only to breast cancer patients but also to their healthy relatives through our magazine GEYSALUS, in order to make them aware of the different therapeutic options they have in case they will become future patients.

With these premises and with a 16-year track record in conducting clinical trials we have become one of the most important breast cancer research groups both nationally and internationally.

\section{KARGER}

Fax +49 7614520714

Information@Karger.de

www.karger.com (c) 2011 S. Karger GmbH, Freiburg 


\section{Clinical and Translational Research}

Since its creation GEICAM has strengthened its research work with more than 75 clinical trials and epidemiological research, both national and international, with the participation of over 42,000 patients. Faithful to our work philosophy, most of the research projects are designed by the group's own members and under strictly scientific criteria.

The group has outstanding examples of these, such as the Alamo Project [4-7] which has made it possible to analyse the way in which the disease is presented and the therapeutic trends in the oncological medical practice in Spain over the last 20 years; the EpiGeicam study [8,9] which has recruited 1,000 breast cancer patients and 1,000 healthy controls in order to analyse the epidemiological aspects of breast cancer development in Spain; or the ExCel trial, which is the leading study in chemoprevention in Spain, it started in 2005 and was recently published in the NEJM [10] showing that an aromatase inhibitor reduced the relative risk of breast cancer development by as much as $65 \%$ in menopausal women at high risk compared to placebo. Efforts to which one can add the GEICAM 9805/Target 0 study, reported in December 2010 in NEJM [11], the first and only clinical trial in the world with available data evaluating the role of chemotherapy with taxanes in the adjuvant treatment of women with breast cancer without axillary involvement. For the first time, with this trial, a Spanish research, developed by our group and with Spanish patients has served to give an approval for a drug by the European Medicines Agency (EMA) as a new standard treatment for early stage breast cancer patients. This study represents a milestone for GEICAM and demonstrates the high level of oncology research in Spain.

Likewise, one of the most important areas of development for GEICAM is translational research. This means that research conducted in the laboratory has its practical reflection in clinical research carried out with patients. The ultimate aim for the results of this basic research is to have a quicker application in drug development as well as to have more efficient and safer treatments. Currently most of our studies have a translational research correlate. For example, in 2009 we published an article on 'Molecular predictors of efficacy of adjuvant weekly paclitaxel in early breast cancer' in Breast Cancer Research and Treatment [12], based on data from the GEICAM 9906 study [13]. We also have exclusively translational studies, e.g. a trial evaluating the likelihood of change in the treatment recommendations after performing the Recurrence Score (RS) in Spanish breast cancer patients, recently published in Annals of Oncology [14].

\section{Early Clinical Research}

In 2009 we established the network of early trialists GEICAM (netGEICAM) with the intention to perform early phase studies with the same quality standards and expertise of our well-known cooperative research group. Our commitment is to collaborate with the sponsors, helping them in the design and conduction of early phase trials. We are focused on phase IB as well as IIA with new drug combinations. Currently netGEICAM comprises 10 hospitals, each with a long history of conducting clinical trials and with strong expertise. This network is coordinated by the experts of the netGEICAM central leading team. At present there are 4 breast cancer studies in progress, and this platform is open to the development of new drugs in other tumour types as well.

\section{Continuous Training and Dissemination}

In addition to research, and as part of our objective of educating and disseminating all matters related to breast cancer, we develop training activities for all the specialists involved in the different areas of treatment of this disease. In this way, the GEICAM multidisciplinary programme for Continuous Medical Education is unique in its genre and constitutes a learning tool for those wishing to complement their knowledge with a rich and plural vision of the most important aspects of breast cancer treatment. Also, we annually organise the Revisión Anual GEICAM de Avances en Cáncer de Mama (RAGMA), which provides an in-depth review of the most important achievements presented at international congresses and in scientific publications each year. These activities, along with the GEICAM International Symposium, which we organise on a biennial basis in Spain, have become essential tools for updating the knowledge of all specialists involved in detecting and treating breast cancer. On April 18th and 19th, 2013 we will host in Valencia the ninth edition of this international symposium.

Finally, we can state that the engagement, enthusiasm and initiative of our members are defining us over the time as a pivotal cooperative group of excellence in breast cancer research.

Roser Trilla (Marketing and Communications Manager), Eva Carrasco (Scientific Director), Miguel Martín (President); GEICAM 


\section{References}

1 Lluch A, Torrecillas L, Barrios $\mathrm{CH}$, Bines J, Gómez H, Getulio J, Ruiz-Borrego M, De la Haba J, Torres R, Ruiz A: CIBOMA/2004-01 a randomised phase III trial assessing adjuvant capecitabine (X) maintenance therapy after standard chemotherapy for triple-negative early breast cancer (EBC). European CanCer Organization (ECCO) 15 and 34th European Society Medical Oncology Multidisciplinary Congress (ESMO). 20-24 September 2009. Berlin. Germany. No poster $\# 5.150$.

2 Lluch A, Gómez H, Ruiz-Borrego M, Bines J, Llombart A, Ramos-Vázquez $\mathrm{M}$, Torres $\mathrm{R}$ Segalla JG, Torrecillas L, Barrios CH: First safety data from a randomised phase III (CIBOMA 2004-01/GEICAM/2003-11) trial assessing adjuvant capecitabine maintenance therapy after standard chemotherapy for triple-negative early breast cancer. 33rd San Antonio Breast Cancer Symposium; 8-12 December 2010. San Antonio. USA

3 Ruiz-Borrego M, Barrios CH, Lluch A, Bines J, Segalla JGM, Ruiz A, Torrecillas L, LlombartCussac A, Torres R, Garcia Saenz JÁ, Lopez Garcia-Asenjo JA, Gomez HL, De la Haba JR, Reyes S, Martinez E, Baena JM, Perez-Michell L, Rodriguez-Lescure A, Anton A, Martin M, on behalf of CIBOMA/GEICAM: Local vs. central laboratory discrepancies in the determination of triple negative breast cancer (TNBC) status in a large phase III (CIBOMA/2004-01/ GEICAM/2003-11) trial assessing adjuvant capecitabine (C) maintenance therapy after standard chemotherapy $(\mathrm{CT})$ in early breast cancer (EBC) patients (pts). 47th American Society Clinical Oncology Annual Meeting. 3-7 June 2011. Chicago. USA. J Clin Oncol 2011;29:(suppl; abstr 1022)

4 Jerez JM, Franco L, Alba E, Llombart-Cussac A, Lluch A, Ribelles N, Munárriz B, Martín M: Improvement of breast cancer relapse prediction in high risk intervals using artificial neural networks. Breast Cancer Res Treat 2005;94:265-272.

5 Jara C, Ruiz A, Martín M, Antón A, Munárriz B, Plazaola A, Schneider J, Martínez del Prado $\mathrm{P}$, Alba E, Fernández-Aramburo A: Influence of timing of initiation of adjuvant chemotherapy over survival in breast cancer: a negative outcome study by the Spanish Breast Cancer Research Group (GEICAM). Breast Cancer Res Treat 2007; 101:215-223.
6 Puente J, López-Tarruella S, Ruiz A, Lluch A, Pastor M, Alba E, de la Haba J, Ramos M, Cirera L, Antón A, Llombart A, Plazaola A, FernándezAramburo A, Sastre J, Díaz-Rubio E, Martin M: Practical prognostic index for patients with metastatic recurrent breast cancer: retrospective analysis of 2,322 patients from the GEICAM Spanish El Alamo Register. Breast Cancer Res Treat 2010; 122:591-600.

7 Jerez JM, Molina I, García-Laencina PJ, Alba E, Ribelles N, Martín M, Franco L: Missing data imputation using statistical and machine learning methods in a real breast cancer problem. Artif Intell Med 2010;50:105-115.

8 Pollán M, Martín M, Sánchez-Rovira P, Pérez B, Antón A, Lluch A, Colomer R, Guillem V: Riesgo de cáncer de mama y estilo de vida en España: consumo de bebidas alcohólicas, hábitos de ingesta y aceite de oliva. [Breast cancer risk and lifestyle in Spain: alcoholic beverage, diet habits and olive oil]. V Simposio sobre Resultados en Investigación Oncológica Fundación Científica AECCC [V Simposium on Oncological Research Results Scientific Foundation AECC]. 17 February 2010. Madrid

9 Pollán M, Guillem V, Martín M, Casas A, Lluch A, Baena JM, Antolín S, Sánchez P, Ramos M, Muñoz M, Jara C., Antón A, López JM, Chacón JI, Moreno F, Arcusa A, Adrover E, Oltra A, González S, Pérez B, on behalf of the EpiGEICAM investigators: Epi-GEICAM-01: Estilo de vida y riesgo de cáncer de mama en España. [Epi-GEICAM-01: Lifestyle and breast cancer in Spain]. VIII Simposio Internacional GEICAM [VIII Simposium International GEICAM]. 31 March-1 April 12011. A Coruña

10 Goss PE, Ingle JN, Alés-Martínez JE, Cheung AM, Chlebowski RT, Wactawski-Wende J, McTiernan A, Robbins J, Johnson KC, Martin LW, Winquist E, Sarto GE, Garber JE, Fabian CJ, Pujol P, Maunsell E, Farmer P, Gelmon KA, Tu D, Richardson H; the NCIC CTG MAP.3 Study Investigators: Exemestane for Breast-Cancer Prevention in Postmenopausal Women. N Engl J Med 2011 23;364:2381-2391.
1 Martín M, Seguí MA, Antón A, Ruiz A, Ramos M, Adrover E, Aranda I, Rodríguez-Lescure A, Grosse R, Calvo L, Barnadas A, Isla D, Martinez del Prado P, Ruiz Borrego M, Zaluski J, Arcusa A, Muñoz M, López Vega JM, Mel JR, Munarriz B, Llorca C, Jara C, Alba E, Florián J, Li J, López García-Asenjo JA, Sáez A, Rios MJ, Almenar S, Peiró G, Lluch A; GEICAM 9805 Investigators: Adjuvant docetaxel for high-risk, node-negative breast cancer. N Engl J Med 2010; 363:2200-2210.

12 Martín M, Rodríguez-Lescure A, Ruiz A, Alba E, Calvo L, Ruiz-Borrego M, Santaballa A Rodríguez CA, Crespo C, Abad M, Domínguez S, Florián J, Llorca C, Méndez M, Godes M, Cubedo R, Murias A, Batista N, García MJ, Caballero R, de Alava E: Molecular predictors of efficacy of adjuvant weekly paclitaxel in early breast cancer. Breast Cancer Res Treat 2010; 123:149-157.

13 Martín M, Rodríguez-Lescure A, Ruiz A, Alba E, Calvo L, Ruiz-Borrego M, Munárriz B, Rodríguez CA, Crespo C, de Alava E, López García-Asenjo JA, Guitián MD, Almenar S, González-Palacios JF, Vera F, Palacios J, Ramos M, Gracia Marco JM, Lluch A, Alvarez I, Seguí MA, Mayordomo JI, Antón A, Baena JM, Plazaola A, Modolell A, Pelegrí A, Mel JR, Aranda E, Adrover E, Alvarez JV, García Puche JL, SánchezRovira P, Gonzalez S, López-Vega JM; GEICAM 9906 Study Investigators: Randomized phase 3 trial of fluorouracil, epirubicin, and cyclophosphamide alone or followed by paclitaxel for early breast cancer. J Natl Cancer Inst 2008;100:805-814

14 Albanell J, González A, Ruiz-Borrego M Alba E, García-Saenz JA, Corominas JM, Burgues O, Furio V, Rojo A, Palacios J, Bermejo B, Martínez-García M, Limon ML, Muñoz AS, Martín M, Tusquests I, Rojo F, Colomer R, Faull I, Lluch A: Prospective transGEICAM study of the impact of the 21-gene recurrence score assay and traditional clinicopathological factors on adjuvant clinical decision making in women with estrogen receptor-positive $(\mathrm{ER}+)$ node-negative breast cancer. Ann Oncol 2011 DOI: 10.1093/annone/ $\underline{\operatorname{mdr} 278}$ 